\title{
PENGARUH KARAKTERISTIK PRIBADI DAN DIMENSI SOSIAL TERHADAP KEMAMPUAN WIRAUSAHA PEREMPUAN
}

\author{
Iqbal Reza Fazlurrahman ${ }^{1)}$, Anna Fariyanti' ${ }^{2)}$, dan Suharno ${ }^{3)}$ \\ 1,2,3) Departemen Agribisnis, Fakultas Ekonomi dan Manajemen, Institut Pertanian Bogor \\ 1)iqbal@iqbalreza.net
}

\begin{abstract}
This research aimed to (1) identify the personal characteristics and social dimensions of women entrepreneur, and (2) to analyze the influence of personal characteristics and social dimensions to women's entrepeurial skills. The analysis used in this research are descriptive and quantitative by using Partial Least Square (PLS) modelling. Result found that both characteristics and social dimension positively and significantly influence entrepreneurial skills of women. Social dimensions is a strong predictor which positively and significantly influence the entrepreneurial skills.
\end{abstract}

Keyword(s): women entrepeneur, personal characterstics, social dimension

\begin{abstract}
ABSTRAK
Penelitian ini bertujuan untuk: (1) mengidentifikasi karakter pribadi dan modal sosial wirausaha perempuan dan (2) menganalisis pengaruh karakter pribadi dan modal sosial terhadap kemampuan wirausaha perempuan. Analisis yang digunakan dalam penelitian ini yaitu analisis deskriptif dan kuantitatif dengan menggunakan pemodelan Partial Least Square (PLS). Pada hasil analisis ditemukan karakter pribadi dan modal sosial secara positif dan signifikan memengaruhi kemampuan wirausaha perempuan. Modal sosial sebagai prediktor kuat yang positif dan signifikan memengaruhi kemampuan kewirausahaan perempuan.
\end{abstract}

Kata Kunci: wirausaha perempuan, karakteristik pribadi, modal sosial

\section{PENDAHULUAN}

Indonesia memiliki potensi untuk meningkatkan pertumbuhan melalui peningkatan partisipasi perempuan dalam perekonomian. Tambunan (2009) menyatakan sebagian besar penduduk miskin di Indonesia adalah perempuan. Hingga saat ini, program pemberdayaan perempuan belum berjalan dengan baik, padahal bila dikembangkan dengan baik dapat mengurangi tingkat kemiskinan.

Hakim (2011) menyatakan perempuan lebih codong memilih bekerja di sektor informal seperti pada perdagangan dan jasa serta pertanian. Lebih dari 70 persen perempuan tinggal di wilayah pedesaan (Elizabeth, 2008). Pemberdayaan perempuan di pedesaan melalui kewirausahaan dianggap mampu mengurangi tingkat kemiskinan (Muljaningsih et al., 2012).

Namun wirausaha perempuan di Indonesia memiliki hambatan-hambatan untuk berkembang, antara lain: (1) konstruksi sosial dan budaya, (2) akses pendidikan rendah, dan (3) dukungan 
akses keuangan yang rendah (Müller, 2006). Tambunan (2012) karakteristik khusus yang dimiliki perempuan, membuat mereka sulit untuk mendapatkan kredit dari lembaga keuangan formal.

Kementerian Koperasi dan Usaha Kecil Menengah (KKUKM) (2012) memperkirakan dari 46 juta pelaku usaha mikro yang ada di Indonesia, sebagian besar merupakan industri rumahan dengan 73 persen diantaranya adalah perempuan. Sedangkan di Kabupaten Bogor terdapat 218.951 wirausaha perempuan atau sekitar 33,88 persen dari total wirausaha (BPS, 2014). Pada umumnya usaha yang dijalani para perempuan tergolong mikro (KPPA, 2012)

Institut Pertanian Bogor (IPB) sebagai memiliki peran pemberdayaan masyarakat sebagaimana diamanatkan UU 12/2012. Kondisi lingkungan sosial masyarakat lingkar kampus IPB tergolong rentan terhadap kemiskinan (Suharyanto, 2007). Sebagian dari masyarakat lingkar kampus memiliki mata pencaharian di bidang pertanian dan wirausaha. Namun keterbatasan membuat kegiatan wirausaha yang dijalankan masyarakat, terutama oleh kamum perempuan sulit berkembang.

Sebagai bentuk pengabdian terhadap masyarakat, Departemen Agribisnis IPB menjalankan inisiatif program Mitra Agribisnis. Mitra Agribisnis merupakan program penyaluran kredit modal dan pengembangan usaha yang disertai dengan penelitian untuk wirausaha perempuan yang tinggal dan menjalankan usaha di lingkar kampus. Program ini dilaksanakan pada Februari hingga Maret tahun 2014.

Pada pelaksanaan program, ditemukan bahwa karakter pribadi pendorong kewirausahaan pada perempuan masih terbatas, kesadaran wirausaha perempuan dalam memanfaatkan kredit usaha masih rendah serta tidak adanya perbedaan antara sebelum dan sesudah pemberian kredit terhadap omset usaha. (Adilah, 2014).

Kurangnya fungsi pendampingan bagi peserta dan keterbatasan waktu pelaksanaan program diduga menjadi penyebab belum efektifnya penyaluran kredit usaha. Dengan demikian, agar program berdampak lebih baik, perlu dilakukan modifikasi dalam penyaluran kredit usaha (Safitri, 2014).

Penelitian ini dilaksanakan sebagai evaluasi terhadap karakter pribadi, modal sosial, dan kemampuan wirausaha perempuan peserta Mitra Agribisnis. Salah satu hasil dari penelitian ini adalah untuk memberi masukan desain program Mitra Agribisnis untuk pelaksanaan di masa mendatang. Oleh karena itu, tujuan dari penelitian ini adalah: (1) mengidentifikasi karakter pribadi dan modal sosial wirausaha perempuan, serta (2) menganalisis pengaruh karakter pribadi dan modal sosial terhadap kemampuan wirausaha perempuan.

\section{TINJAUAN PUSTAKA}

\section{Karakter Pribadi dan Kemampuan Wirausaha}

Kor et al. (2007) menjelaskan karakter individu berkembang melalui proses pola asuh, interaksi sosial, pengalaman, pelatihan, dan pendidikan. 
Karakter pribadi merupakan salah satu faktor penentu kesuksesan seorang wirausaha (Chaudhary et al., 2012). Baum dan Locke (2004) menjelaskan bahwa Karakter merupakan kepribadian suatu individu yang dapat membuat perbedaan antara individu satu dengan individu lain pada situasi yang sama. Karakter merupakan kepribadian yang bersifat unik, subjektif, dipengaruhi oleh pengetahuan individu, nilai, persepsi dan pengalaman yang tidak mudah ditiru.

Bird (1995) berpendapat terdapat beberapa karakter pendorong kewirausahaan, antara lain: (1) pengetahuan khusus, (2) motivasi, (3) sifat, (4) proyeksi diri, (5) peran sosial, dan (6) keterampilan.

Ekpe (2011) menyatakan bahwa karakter dan faktor-faktor pendorong kesuksesan kewirausahaan perempuan antara lain (1) pendidikan, (2) usia, (3) lama pengalaman usaha, (4) status keluarga, (5) kemampuan bahasa, (6) pelatihan, (7) motivasi, dan (8) keberadaan kelompok sosial pendukung.

Mitchelmore dan Rowley (2010) menyatakantiga kategori kapasitas wirausaha, antara lain: (1) sikap, (2) pengetahuan, dan (3) keterampilan. Chaifetz (2010) menyatakan kemampuan kewirausahaan sebagai kelompok kapasitas yang relevan dalam mendorong kesuksesan usaha. Kemampuan kewirausahaan terbagi dua, yaitu (1) keterampilan kewirausahaan, yang dibutuhkan untuk memulai usaha baru, dan (2) keterampilan manajerial yang dibutuhkan dalam pengembangan usaha.

Rauch dan Frese (2000) menyatakan faktor-faktor penentu keberhasilan dalam wirausaha antara lain: (1) locus of control, (2) pengambilan risiko, (3) sumber daya manusia, (4) perencanaan dan strategi, (5) inovasi, (6) orientasi tujuan, dan (7) kondisi lingkungan.

\section{Modal Sosial Wirausaha}

Modal sosial bersumber dari interaksi hubungan pasar, sosial, dan hierarkis yang menghasilkan modal sosial wirausaha. Modal sosial berpengaruh bagi pelaku wirausaha antara lain memberikan peningkatan: (1) kesuksesan karir, (2) kompensasi keuangan, (3) peluang pekerjaan, (4) pertukaran sumber daya dan inovasi produk, (5) penciptaan modal intelektual, (6) efektivitas kerja (7) penciptaan kewirausahaan, dan (8) pembentukan usaha baru (Adler dan Kwon, 2002).

Baron dan Markman (2003) menyatakan modal sosial dapat memengaruhi kesuksesan wirausaha, seperti reputasi, kemampuan bersosialisasi, beradaptasi dengan lingkungan sosial, dan dukungan sosial. Tingkat modal sosial seperti persepsi sosial, adaptasi, sifat keterbukaan, dan kecerdasan emosi berpengaruh positif kepada keuntungan finansial usaha.

Okafor dan Amalu (2010) menyatakan bahwa modal sosial berpengaruh positif terhadap motivasi dan kemampuan manajerial perempuan dalam menghadapi tantangan wirausaha.

Noureen dan Arsyad (2011) menemukan dampak modal sosial, dimana kepercayaan dan dukungan dari kelompok, keluarga, dan hubungan informal institusi usaha memberikan 
dorongan untuk memulai usaha dan kemajuan usaha.

\section{Kredit dan Pemberdayaan Perempuan}

Pemberian kredit mikro bagi perempuan di desa menunjukkan peningkatan perekonomian dan kehidupan sosial serta mengurangi tingkat kemiskinan (Develtere dan Huybrechts, 2002; Sharma et al., 2012; Lavoori dan Paramanik, 2014).

Perempuan di desa memiliki berbagai hambatan yang membuat usaha lebih sulit untuk berkembang, hambatan ini antara lain: keterbatasan dukungan keuangan, keterbatasan informasi, stigma sosial, keterbatasan akses informasi, keterbatasan akses pasar, serta faktor kognitif (Afrin et al., 2008),

Pemberian kredit mikro bagi perempuan di desa juga berdampak pada penciptaan tenaga kerja, peningkatan produktivitas, pengadaan jaminan ekonomi, peningkatan kesehatan, dan peningkatan kesejahteraan. Selain itu, secara individu berdampak pada peningkatan kepercayaan diri, pemberdayaan sosial, kesadaran pendidikan, dan peningkatan kemampuan manajerial (Cheston dan Kuhn, 2002; Afrin et al., 2008).

Vadde dan Ratnam (2014) mengenai pelatihan dan pertemuan kelompok dapat meningkatkan karakter dan perilaku wirausaha perempuan yang tergabung dalam kelompok. Karlan dan Vardivia (2006) meyatakan pemberian kredit yang disertai program pemberdayaan melalui pelatihan pada wirausaha perempuan menghasilkan peningkatan pengetahuan usaha, kemampuan manajerial, dan penghasilan. Pemberian pelatihan juga memberikan manfaat bagi LKM yaitu peningkatan rasio pembayaran kredit dan retensi klien.

Das (2000) menyatakan motivasi perempuan secara umum adalah untuk mencapai kemandirian dan keinginan untuk melakukan pencapaian. Khanka (2002) menyatakan perempuan secara umum memiliki karakter individu antara lain: (1) inovasi, (2) motivasi dan tekad, (3) kemampuan sosial, (4) disiplin, dan (5) pengambikan risiko.

Ekpe et al. (2010) menyatakan wirausaha perempuan memiliki karakter baik serta motivasi yang tinggi untuk mencapai kesuksesan, namun memiliki pengetahuan dan pengalaman usaha yang rendah. Pemberian kredit yang disertai pelatihan usaha yang dilakukan dalam kelompok sosial berpengaruh terhadap peningkatan penghasilan usaha.

Loice dan Razia (2013) menyatakan bahwa pemberian pelatihan kewirausahaan dan pemberian kredit mikro kepada wirausaha perempuan berdampak positif terhadap pemberdayaan perempuan. Peningkatan terhadap akses kredit dan simpanan, dukungan dari kelompok sosial, serta pemberian pelatihan yang disesuaikan dengan kebutuhan wirausaha perempuan dapat meningkatkan kesuksesan usaha dan pengembalian kredit mikro.

\section{METODE PENELITIAN}

\section{Lokasi dan Waktu Penelitian}

Lokasi penelitian ini di desa Cihideung Ilir, Kecamatan Dramaga, Kabupaten Bogor. Penelitian dilakukan mulai bulan April hingga Juni 2015. 
Penentuan lokasi penelitian dilakukan secara sengaja, berdasarkan pada pelaksanaan program Mitra Agribisnis di tahun 2014.

\section{Jenis dan Sumber Data}

Data yang dikumpulkan terdiri dari data primer dan data sekunder. Data primer didapatkan melalui wawancara dengan panduan kuesioner sedangkan data sekunder yang didapatkan dari Kementerian Koperasi dan Usaha Kecil Menengah, BPS serta publikasi ilmiah yang relevan.

\section{Metode Penentuan Responden}

Metode penentuan responden dalam penelitian ini adalah sensus terhadap seluruh wirausaha perempuan peserta program kredit Mitra Agribisnis di Desa Cihideung Ilir yang berjumlah 30 orang.

\section{Metode Analisis Data}

Data primer terkait karakter pribadi dan modal sosial yang telah dikumpulkan dalam penelitian ini, diolah dan dianalisis secara deskriptif. Data kuantitatif diolah dengan menggunakan analisis Partial Least Square modelling (PLS) yang

Tabel 1. Keterangan Variabel-Variabel pada Path Diagram

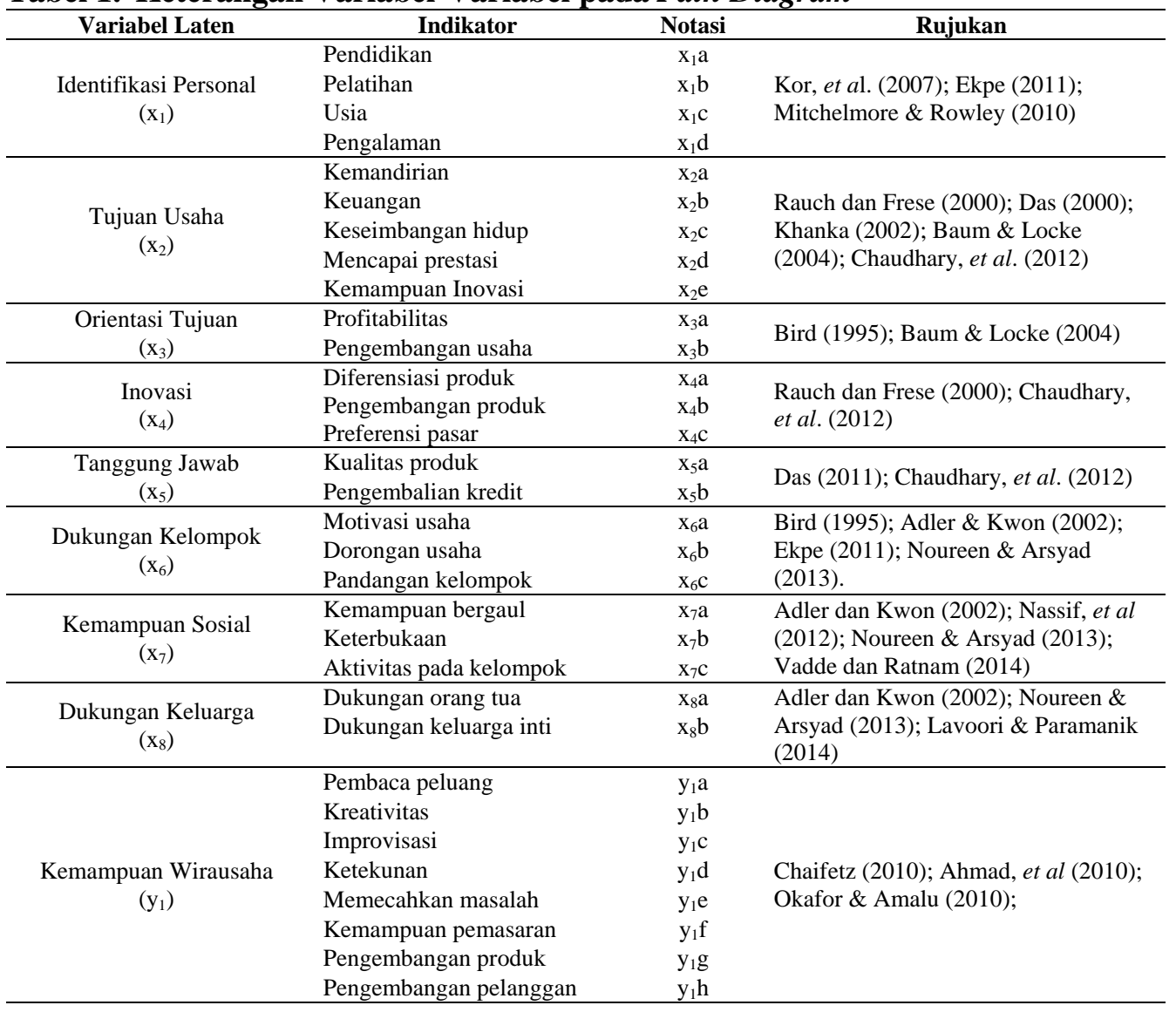


menggunakan bantuan software SmartPLS 3.2.1.

\section{Pendekatan Partial Least Square}

Partial Least Square (PLS) merupakan pendekatan Structural Equation Modeling (SEM) yang berbasis varian. Menurut Ghozali (2008) PLS bersifat predictive model, metode ini sangat kuat karena tidak didasarkan oleh banyak asumsi, data tidak harus terdistribusi dengan normal multivariate, dan sampel tidak harus besar.

\section{Prosedur PLS Modeling}

Ghozali (2008) menyatakan PLS mempunyai dua model indikator, yaitu (1) model indikator refleksif, dan (2) model indikator formatif. Evaluasi terhadap model PLS dapat dilakukan dengan dua cara, yaitu (1) model pengukuran dan (2) model struktural.

\section{Implementasi Model}

Pengukuran indikator dari tiap variabel dilakukan dengan skala ordinal yang mengacu pada prinsip skala Likert. Variabel-variabel laten diidentifikasi berdasarkan teori yang telah dibangun sebelumnya dengan penjelasan yang dapat dilihat pada Tabel 1. Hubungan yang terdapat dalam model dapat dilihat melalui diagram lintas Gambar 1.

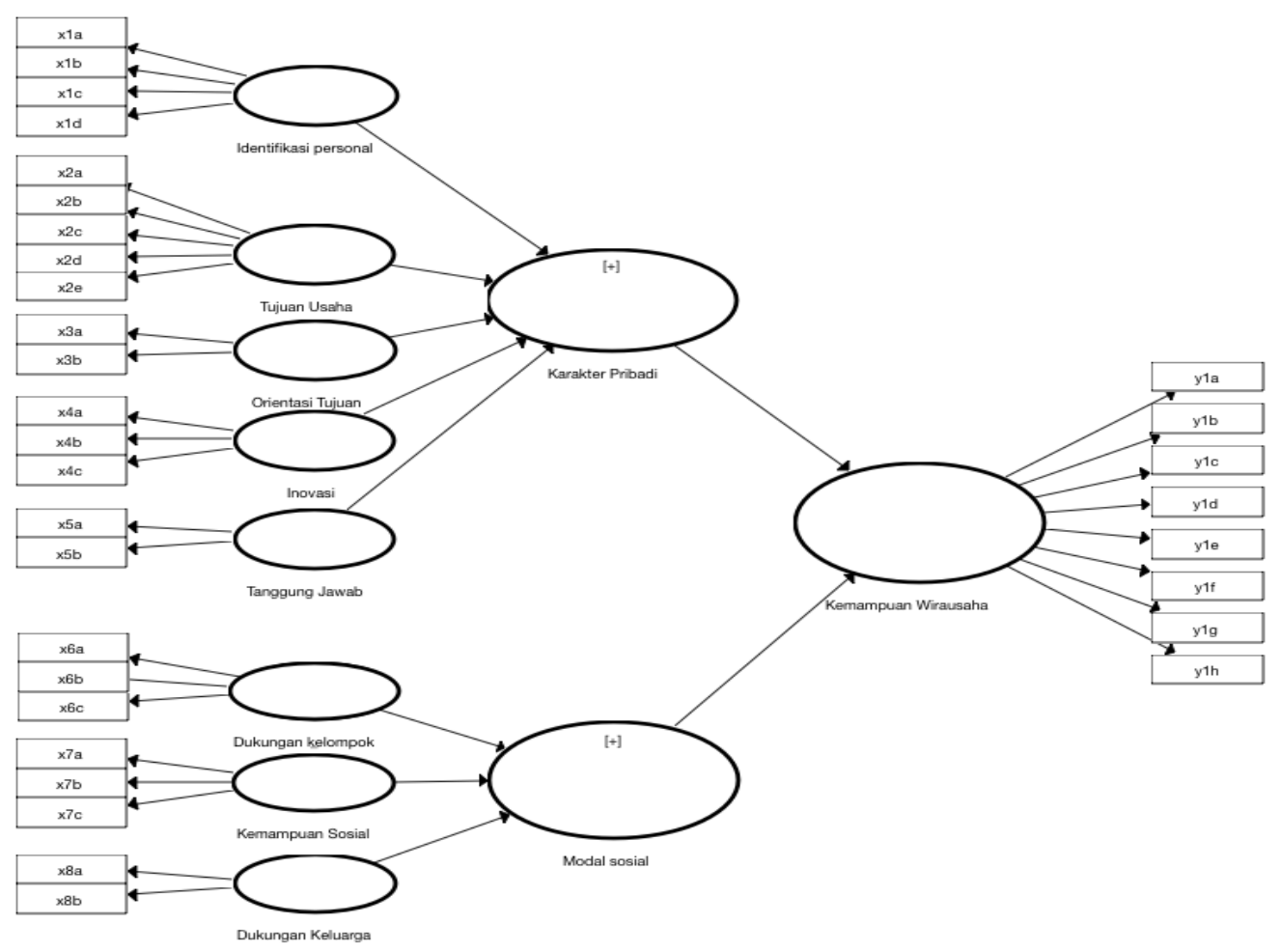

Gambar 1. Model Awal Path Diagram Partial Least Square 
HASIL DAN PEMBAHASAN

Karakter Pribadi, Modal Sosial, dan Kemampuan Wirausaha

Pengukuran indikator dari tiap variabel karakter pribadi, modal sosial, dan kemampuan wirausaha dilakukan dengan skala ordinal yang mengacu pada prinsip skala Likert.

\section{Karakter Pribadi}

Karakter pribadi wirausaha perempuan dapat dilihat dari identifikasi, tujuan usaha, orientasi usaha, inovasi, dan tanggung jawab. Tabel 2 menunjukkan sebaran rataan skor karakter pribadi.

Identifikasi personal responden tergolong tinggi menandakan perempuan peserta program Mitra Agribisnis memahami bahwa pendidikan, pelatihan, usia, dan pengalaman dianggap penting terhadap kemajuan usaha.

Motivasi usaha responden tergolong rendah, hal ini diakibatkan sebagian tujuan usaha termasuk ke dalam kategori rendah hal ini diakibatkan sebagian besar dari perempuan melihat wirausaha sebagai usaha yang mereka jalani untuk memenuhi kebutuhan ekonomi.

Orientasi usaha tergolong tinggi, menunjukkan sebagian dari perempuan menginginkan usahanya dapat maju dan berkembang dengan lebih baik, namun lainnya merasa usaha yang dimiliki pada saat ini telah cukup.

Inovasi usaha responden tergolong tinggi, ini mereka memperhatikan keinginan pelanggan dengan menyediakan produk yang sering ditanyakan oleh pelanggan.
Tabel 1. Sebaran Rataan Skor Berdasarkan Karakter Pribadi

\begin{tabular}{|c|c|c|}
\hline Indikator & $\begin{array}{c}\text { Rataan } \\
\text { Skor }\end{array}$ & Kategori \\
\hline \multicolumn{3}{|l|}{ Identifikasi } \\
\hline \multicolumn{3}{|l|}{ Personal: } \\
\hline 1. Pendidikan & 3,90 & Tinggi \\
\hline 2. Pelatihan & 3,83 & Tinggi \\
\hline 3. Usia & 3,70 & Tinggi \\
\hline 4. Pengalaman & 3,83 & Tinggi \\
\hline \multicolumn{3}{|l|}{ Tujuan Usaha: } \\
\hline 1. Kemandirian & 3,00 & Rendah \\
\hline 2. Keseimbangan & 2,77 & Rendah \\
\hline 3. Prestasi & 2,57 & Rendah \\
\hline 4. Inovasi & 3,40 & Tinggi \\
\hline 5. Status sosial & 3,00 & Rendah \\
\hline \multicolumn{3}{|l|}{ Orientasi Usaha: } \\
\hline 1. Pengembangan & 3,40 & Tinggi \\
\hline 2. Profitabilitas & 3,70 & Tinggi \\
\hline \multicolumn{3}{|l|}{ Inovasi } \\
\hline 1. Diferensiasi & 3,45 & Tinggi \\
\hline $\begin{array}{l}\text { 2. Pengembangan } \\
\text { produk }\end{array}$ & 4,00 & Tinggi \\
\hline 3. Preferensi pasar & 4,00 & Tinggi \\
\hline \multicolumn{3}{|l|}{ Tanggung Jawab } \\
\hline 1. Kualitas produk & 3,93 & Tinggi \\
\hline $\begin{array}{l}\text { 2. Pengembalian } \\
\text { kredit }\end{array}$ & 3,83 & Tinggi \\
\hline $\begin{array}{l}\text { 3. Manajemen } \\
\text { keuangan }\end{array}$ & 2,47 & Rendah \\
\hline $\begin{array}{l}\text { Keterangan kategori: } \\
1,00 \leq \text { sangat rendah }<2,00 ; \\
2,01 \leq \text { rendah }<3,00 ; \\
3,01 \leq \text { tinggi }<4,00 ; \\
4,01 \leq \text { sangat tinggi }<5,00\end{array}$ & & \\
\hline
\end{tabular}

Tanggung jawab responden tergolong tinggi kecuali manajemen keuangan, hal ini menunjukkan bahwa sebagian besar perempuan tidak mampu melakukan pengelolaan terpisah antara keuangan usaha dan rumah tangga.

\section{Modal Sosial}

Modal sosial dapat dilihat dari dukungan kelompok, kemampuan sosial, dan dukungan keluarga. Tabel 3 me- 
nunjukkan sebaran rataan skor modal sosial.

Tabel 2. Sebaran Rataan Skor Berdasarkan Modal Sosial

\begin{tabular}{lcc}
\hline \multicolumn{1}{c}{ Indikator } & $\begin{array}{c}\text { Rataan } \\
\text { Skor }\end{array}$ & Kategori \\
\hline $\begin{array}{l}\text { Dukungan kelompok: } \\
\text { 1. Motivasi usaha }\end{array}$ & 3,03 & Tinggi \\
2. Dorongan usaha & 2,97 & $\begin{array}{c}\text { Rendah } \\
\text { 3. Pandangan kelompok }\end{array}$ \\
2,83 & Rendah \\
\hline Kemampuan sosial: & & \\
1. Kemampuan bergaul & 3,33 & Tinggi \\
2. Keterbukaan & 3,43 & Tinggi \\
3. Aktifitas kelompok & 2,83 & Rendah \\
\hline $\begin{array}{l}\text { Dukungan keluarga: } \\
\text { 1. Dukungan orang tua }\end{array}$ & 4,13 & Sangat \\
& & tinggi \\
2. Dukungan keluarga & 4,27 & $\begin{array}{c}\text { Sangat } \\
\text { tinggi }\end{array}$ \\
\hline
\end{tabular}

Keterangan kategori:

$1,00 \leq$ sangat rendah $<2,00$;

$2,01 \leq$ rendah $<3,00$;

$3,01 \leq$ tinggi $<4,00$;

$4,01 \leq$ sangat tinggi $<5,00$

Dukungan kelompok tergolong kategori rendah, hal ini diakibatkan wirausaha perempuan kurang merasakan manfaat kelompok sosial di lingkungan mereka.

Kemampuan sosial tergolong tinggi menunjukkan responden memiliki kemampuan sosial yang baik dan memiliki sikap terbuka. Sikap ini baik untuk mendorong kemajuan usaha. Aktifitas responden dalam kelompok tergolong rendah, hal ini terkait dengan kondisi kelompok sosial kurang aktif dalam membuat kegiatan pendukung kewirausahaan.

Dukungan keluarga tergolong sangat tinggi, menandakan mayoritas perempuan mendapatkan dukungan yang sangat baik dari keluarga mereka, baik dari orang tua maupun keluarga inti.

\section{Kemampuan Wirausaha}

Kemampuan wirausaha merupakan penilaian kecakapan wirausaha responden. Tabel 4 menunjukkan sebaran rataan skor kemampuan wirausaha.

Tabel 3. Sebaran Rataan Skor Berdasarkan Kemampuan Wirausaha

\begin{tabular}{|c|c|c|}
\hline Indikator & $\begin{array}{c}\text { Rataan } \\
\text { Skor }\end{array}$ & Kategori \\
\hline $\begin{array}{l}\text { 1. Membaca } \\
\text { peluang }\end{array}$ & 3,93 & Tinggi \\
\hline 2. Kreatifitas & 3,83 & Tinggi \\
\hline 3. Improvisasi & 3,80 & Tinggi \\
\hline 4. Ketekunan & 4,03 & $\begin{array}{l}\text { Sangat } \\
\text { tinggi }\end{array}$ \\
\hline $\begin{array}{l}\text { 5. Memecahkan } \\
\text { masalah }\end{array}$ & 3,96 & Tinggi \\
\hline $\begin{array}{l}\text { 6. Kemampuan } \\
\text { pemasaran }\end{array}$ & 3,93 & Tinggi \\
\hline $\begin{array}{l}\text { 7. Pengembangan } \\
\text { produk }\end{array}$ & 3,83 & Tinggi \\
\hline $\begin{array}{l}\text { 8. Pengembangan } \\
\text { pelanggan }\end{array}$ & 3,80 & Tinggi \\
\hline
\end{tabular}

Keterangan kategori:

$1,00 \leq$ sangat rendah $<2,00$;

$2,01 \leq$ rendah $<3,00$;

$3,01 \leq$ ting $i<4,00$;

$4,01 \leq$ sangat tinggi $<5,00$

Kemampuan wirausaha tinggi menunjukkan secara responden memiliki kemampuan wirausaha yang baik. Kemampuan wirausaha merupakan pendorong kemajuan usaha.

\section{Evaluasi Model Pengukuran}

Hasil seluruh kriteria untuk setiap indikator dan variabel laten setelah beberapa indikator di hilangkan dapat dilihat pada Tabel 5. Nilai $t$-statistics seluruh indikator lebih besar dari nilai $t$ - 
Tabel 4. Nilai Outer Loading, AVE dan Composite Reliability

\begin{tabular}{|c|c|c|c|c|c|c|}
\hline Variabel Laten & & Indikator & $\begin{array}{c}\text { Outer } \\
\text { Loading }\end{array}$ & $A V E$ & $\begin{array}{l}\text { Composite } \\
\text { Reliability }\end{array}$ & t-statistics \\
\hline \multirow{4}{*}{$\begin{array}{l}\text { Identifikasi } \\
\text { Personal } \\
\left(\mathrm{x}_{1}\right)\end{array}$} & $\mathrm{x}_{1} \mathrm{a}$ & Pendidikan & 0,837 & \multirow{4}{*}{0,759} & \multirow{4}{*}{0,924} & 2,749 \\
\hline & $\mathrm{x}_{1} \mathrm{~b}$ & Pelatihan & 0,825 & & & 2,747 \\
\hline & $\mathrm{x}_{1} \mathrm{C}$ & Usia & 0,601 & & & 1,612 \\
\hline & $\mathrm{x}_{1} \mathrm{~d}$ & Pengalaman & 0,783 & & & 2,771 \\
\hline \multirow{5}{*}{$\begin{array}{l}\text { Tujuan Usaha } \\
\qquad\left(\mathrm{x}_{2}\right)\end{array}$} & $\mathrm{X}_{2} \mathrm{a}$ & Kemandirian & 0,728 & \multirow{5}{*}{0,668} & \multirow{5}{*}{0,909} & 4,957 \\
\hline & $\mathrm{x}_{2} \mathrm{~b}$ & Keuangan & 0,871 & & & 7,702 \\
\hline & $\mathrm{x}_{2} \mathrm{C}$ & Keseimbangan hidup & 0,708 & & & 5,357 \\
\hline & $\mathrm{x}_{2} \mathrm{~d}$ & Mencapai prestasi & 0,809 & & & 5,607 \\
\hline & $\mathrm{x}_{2} \mathrm{e}$ & Kemampuan Inovasi & 0,855 & & & 6,913 \\
\hline \multirow{2}{*}{$\begin{array}{c}\text { Orientasi Tujuan } \\
\left(\mathrm{x}_{3}\right)\end{array}$} & $\mathrm{x}_{3} \mathrm{a}$ & Profitabilitas & 0,830 & \multirow{2}{*}{0,625} & \multirow{2}{*}{0,767} & 4,341 \\
\hline & $\mathrm{x}_{3} \mathrm{~b}$ & Pengembangan usaha & 0,695 & & & 3,653 \\
\hline \multirow{3}{*}{$\begin{array}{l}\text { Inovasi } \\
\left(\mathrm{x}_{4}\right)\end{array}$} & $\mathrm{X}_{4} \mathrm{a}$ & Diferensiasi produk & 0,818 & \multirow{3}{*}{0,788} & \multirow{3}{*}{0,918} & 8,025 \\
\hline & $\mathrm{x}_{4} \mathrm{~b}$ & Pengembangan produk & 0,878 & & & 9,197 \\
\hline & $\mathrm{x}_{4} \mathrm{C}$ & Preferensi pasar & 0,938 & & & 14,154 \\
\hline \multirow{2}{*}{$\begin{array}{c}\text { Tanggung Jawab } \\
\left(\mathrm{x}_{5}\right)\end{array}$} & $\mathrm{X}_{5} \mathrm{a}$ & Kualitas produk & 0,923 & \multirow{2}{*}{0,869} & \multirow{2}{*}{0,930} & 12,955 \\
\hline & $\mathrm{x}_{5} \mathrm{~b}$ & Pengembalian kredit & 0,930 & & & 11,944 \\
\hline \multirow{2}{*}{$\begin{array}{c}\text { Dukungan } \\
\text { Kelompok }\left(\mathrm{x}_{6}\right)\end{array}$} & $\mathrm{x}_{6} \mathrm{a}$ & Motivasi usaha & 0,942 & \multirow{2}{*}{0,950} & \multirow{2}{*}{0,974} & 4,490 \\
\hline & $\mathrm{x}_{6} \mathrm{C}$ & Pandangan kelompok & 0,932 & & & 4,198 \\
\hline \multirow{3}{*}{$\begin{array}{l}\text { Kemampuan } \\
\text { Sosial }\left(\mathrm{x}_{7}\right)\end{array}$} & $\mathrm{x}_{7} \mathrm{a}$ & Kemampuan bergaul & 0,934 & \multirow{3}{*}{0,796} & \multirow{3}{*}{0,921} & 30,416 \\
\hline & $\mathrm{x}_{7} \mathrm{~b}$ & Keterbukaan & 0,908 & & & 27,145 \\
\hline & $\mathrm{X}_{7} \mathrm{C}$ & Aktivitas kelompok & 0,832 & & & 8,817 \\
\hline \multirow{2}{*}{$\begin{array}{c}\text { Dukungan } \\
\text { Keluarga }\left(\mathrm{x}_{8}\right)\end{array}$} & $\mathrm{x}_{8} \mathrm{a}$ & Dukungan orang tua & 0,952 & \multirow{2}{*}{0,874} & \multirow{2}{*}{0,933} & 16,667 \\
\hline & $\mathrm{x}_{8} \mathrm{~b}$ & Dukungan keluarga & 0,918 & & & 8,174 \\
\hline \multirow{8}{*}{$\begin{array}{c}\text { Kemampuan } \\
\text { wirausaha }\left(\mathrm{y}_{1}\right)\end{array}$} & $\mathrm{y}_{1} \mathrm{a}$ & Pembaca peluang & 0,864 & \multirow{8}{*}{0,772} & \multirow{8}{*}{0,964} & 10,148 \\
\hline & $\mathrm{y}_{1} \mathrm{~b}$ & Kreativitas & 0,932 & & & 16,943 \\
\hline & $\mathrm{y}_{1} \mathrm{C}$ & Improvisasi & 0,934 & & & 25,610 \\
\hline & $\mathrm{y}_{1} \mathrm{~d}$ & Ketekunan & 0,713 & & & 4,723 \\
\hline & $\mathrm{y}_{1} \mathrm{e}$ & Memecahkan masalah & 0,860 & & & 12,190 \\
\hline & $\mathrm{y}_{1} \mathrm{f}$ & Kemampuan pemasaran & 0,937 & & & 25,576 \\
\hline & $\mathrm{y}_{1} \mathrm{~g}$ & Pengembangan produk & 0,906 & & & 25,808 \\
\hline & $\mathrm{y}_{1} \mathrm{~h}$ & Pengembangan pelanggan & 0,859 & & & 18,203 \\
\hline
\end{tabular}

table $(\alpha=5 \%)$, yaitu sebesar 1,96 . Hal ini mengindikasikan bahwa setiap peubah indikator valid untuk mengukur konstruk. Tabel 5 juga menunjukkan bahwa semua nilai composite reliability $>0,7$, menunjukkan indikator-indikator yang digunakan pada penelitian ini mempunyai reliabilitas yang baik.

\section{Evaluasi Model Struktural}

Evaluasi model struktural dapat dilakukan dengan melihat nilai $R$-square pada peubah laten endogen serta path coefficient dan signifikansi. Keterangan $R$-square pada variabel laten menunjukkan seberapa besar variabel laten eksogen mampu menjelaskan variabel laten tersebut.

Tabel 5. Nilai R square

\begin{tabular}{ll}
\hline Variabel Laten & $\mathbf{R}^{\mathbf{2}}$ \\
\hline Modal Sosial & 0,988 \\
Karakter Pribadi & 0,730 \\
Kemampuan Wirausaha & 0,546 \\
\hline
\end{tabular}

Pada Tabel 6 dapat dilihat bahwa nilai $R$-square kemampuan wirausaha sebesar 54,60 persen, artinya keragaman kemampuan wirausaha dapat dijelaskan oleh karakter pribadi dan modal sosial sebesar 54,60 persen, sisanya sebesar 45,40 persen dijelaskan oleh peubah lain. 


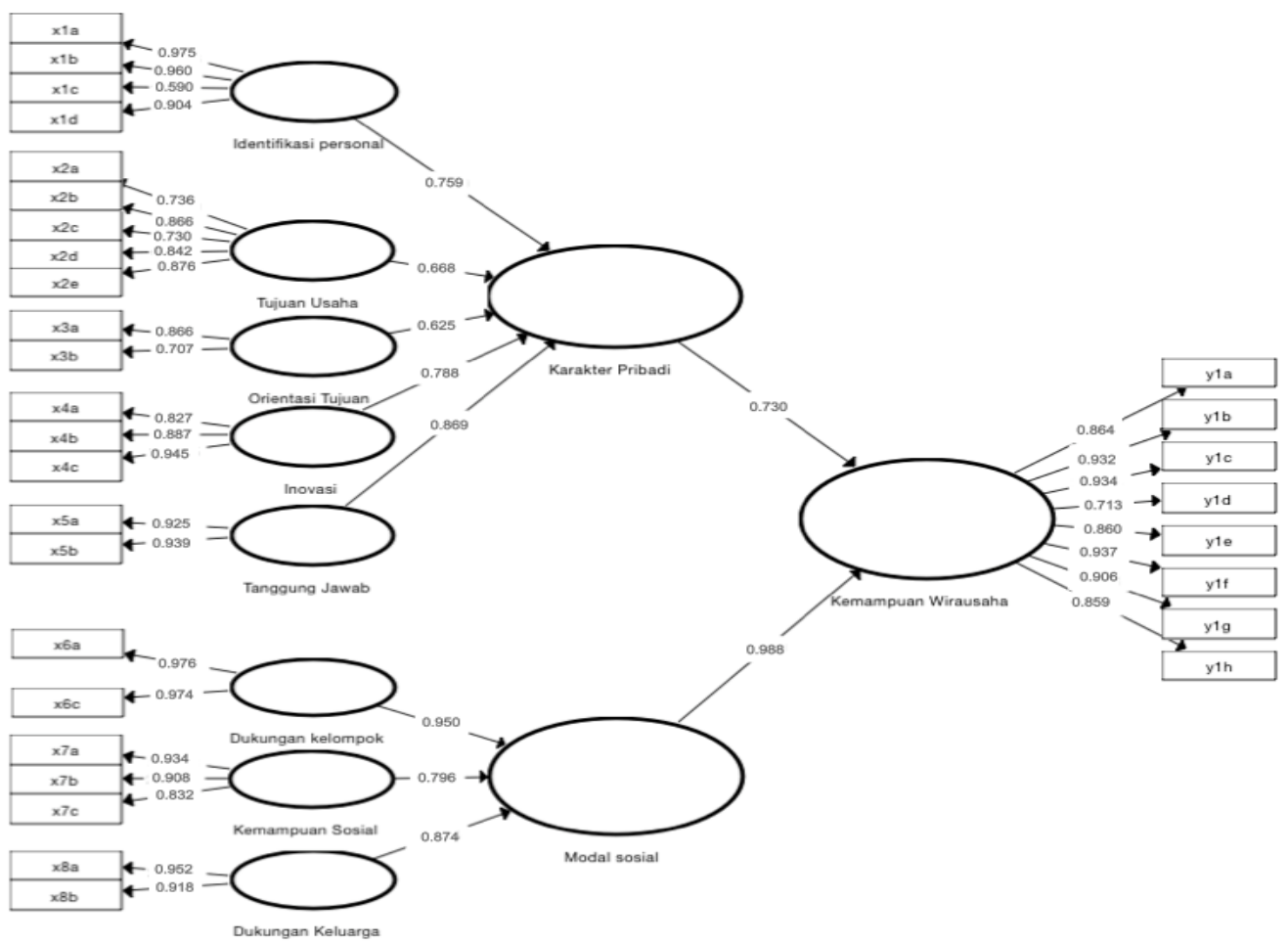

\section{Gambar 2. Nilai Loading pada Diagram Jalur Persamaan Struktural PLS}

Gambar 2 menampilkan nilai loading pada diagram jalur persamaan PLS.

Dapat disimpulkan bahwa keragaman kemampuan wirausaha sudah cukup baik dijelaskan oleh karakter pribadi dan modal sosial. Nilai $R$-square modal sosial merupakan nilai yang paling tinggi.

Nilai effect size $f$ square mengukur seberapa besar pengaruh yang dimiliki sebuah variabel dalam membentuk nilai $\mathrm{R}^{2}$ variabel lainnya. Adapun nilai Nilai $f$ square dapat dilihat pada Tabel 7. Nilai $f$ square yang bernilai 0,$02 ; 0,15$; dan 0,35 menandakan pengaruh yang dimiiki variabel sebagai pembentukan nilai $\mathrm{R}^{2}$ dan $\mathrm{R}^{2}$ kecil, sedang, dan besar. (Widjayanto 1998).
Nilai $f$ square variabel kemampuan sosial terhadap modal sosial merupakan nilai yang paling tinggi. Adapun hasil koefisien parameter dan $t$-statistics untuk setiap hubungan antar variabel laten berdasarkan output PLS dapat dilihat pada Tabel 7. Taraf nyata yang digunakan adalah 5 persen $(\alpha=5 \%)$ sehingga nilai $t$ table sebesar 1,96. Jika t-statistics melebihi nilai t-table, maka variabel laten terbukti nyata.

\section{Pengaruh Karakter Pribadi dan Modal Sosial terhadap Kemampuan Wira- usaha Perempuan}

Chaifetz (2010) menyatakan kemampuan kewirausahaan merupakan kelompok kapasitas tertentu yang relevan 


\begin{tabular}{lrrrc}
\hline & $\begin{array}{c}\text { Original } \\
\text { Sample }\end{array}$ & $\begin{array}{c}\text { Sample } \\
\text { Mean }\end{array}$ & $\begin{array}{c}\text { Standard } \\
\text { Deviation }\end{array}$ & $\begin{array}{c}\boldsymbol{t} \text { - } \\
\text { Statistics }\end{array}$ \\
\hline Dukungan kelompok -> Modal Sosial & 0,002 & 0,023 & 0,042 & 0,049 \\
$\begin{array}{l}\text { Dukungan keluarga -> Modal Sosial } \\
\text { Identifikasi personal -> Karakteristik }\end{array}$ & 22,292 & 33,684 & 33,229 & 0,671 \\
& 0,024 & 0,105 & 0,161 & 0,147 \\
$\begin{array}{l}\text { Pribadi } \\
\text { Inovasi -> Karakteristik Pribadi }\end{array}$ & 0,019 & 0,127 & 0,230 & 0,083 \\
Karakteristik Pribadi -> Kemampuan & 0,061 & 0,134 & 0,165 & 0,369 \\
$\begin{array}{l}\text { Wirausaha } \\
\text { Kemampuan sosial -> Modal Sosial }\end{array}$ & 23,812 & 32,158 & 41,246 & 0,577 \\
$\begin{array}{l}\text { Modal Sosial -> Kemampuan } \\
\text { Wirausaha }\end{array}$ & 0,391 & 0,526 & 0,475 & 0,823 \\
$\begin{array}{l}\text { Orientasi Tujuan -> Karakteristik } \\
\text { Pribadi }\end{array}$ & 0,235 & 0,434 & 0,764 & 0,308 \\
$\begin{array}{l}\text { Tanggung jawab -> Karakteristik } \\
\text { Pribadi }\end{array}$ & 0,204 & 0,308 & 0,339 & 0,603 \\
Tujuan usaha -> Karakteristik Pribadi & 0,127 & 0,237 & 0,257 & 0,492 \\
\hline
\end{tabular}

dalam mendorong kesuksesan. Ahmad, et al. (2010) menyatakan untuk mengubah kesempatan menjadi hasil positif, wirausaha harus dapat mengelola sumberdaya internal dan eksternal mereka. Secara internal, karakter pribadi seperti visi, motivasi, tujuan usaha, inovasi, tanggung jawab, dan kemampuan untuk membaca peluang merupakan kapasitas yang perlu dikembangkan. Secara eksternal, dukungan keluarga dan kelompok pendukung dapat menjadi mendorong kesuksesan wirausaha. Kemampuan kewirausahaan merupakan mekanisme dimana kemungkinan mencapai kesuksesan usaha dapat ditingkatkan melalui faktor-faktor yang mendukungnya.

Berdasarkan hasil pada output pengolahan data pada Tabel 8. Nilai $t$ statistics yang diperoleh dari hubungan antara peubah karakter pribadi kurang dari dari 1,96. Hal ini menunjukkan

\section{Tabel 7. Path Coefficients}

\begin{tabular}{lrrcc}
\hline Pengaruh antar variabel & $\begin{array}{c}\text { Original } \\
\text { Sample }\end{array}$ & $\begin{array}{c}\text { Sample } \\
\text { Mean }\end{array}$ & $\begin{array}{c}\text { Standard } \\
\text { Deviation }\end{array}$ & $\begin{array}{c}\text { t- } \\
\text { Statistics }\end{array}$ \\
\hline Dukungan kelompok -> Modal Sosial & $-0,005$ & $-0,006$ & 0,015 & $0,358^{\mathrm{a}}$ \\
Dukungan keluarga -> Modal Sosial & 0,568 & 0,570 & 0,090 & 6,336 \\
Identifikasi personal -> Karakter Pribadi & $-0,086$ & $-0,082$ & 0,151 & $0,571^{\mathrm{a}}$ \\
Inovasi -> Karakter Pribadi & 0,108 & 0,107 & 0,208 & $0,521^{\mathrm{a}}$ \\
Karakter Pribadi -> Kemampuan & 0,224 & 0,240 & 0,215 & $1,045^{\mathrm{a}}$ \\
Wirausaha & & & & \\
Kemampuan sosial -> Modal Sosial & 0,618 & 0,609 & 0,081 & 7,586 \\
Modal Sosial -> Kemampuan Wirausaha & 0,569 & 0,558 & 0,190 & 2,988 \\
Tujuan usaha -> Karakter Pribadi & 0,240 & 0,240 & 0,135 & $1,784^{\mathrm{a}}$ \\
Orientasi Tujuan -> Karakter Pribadi & 0,348 & 0,339 & 0,177 & 1,971 \\
Tanggung jawab -> Karakter Pribadi & 0,347 & 0,342 & 0,193 & $1,799^{\mathrm{a}}$ \\
\hline
\end{tabular}




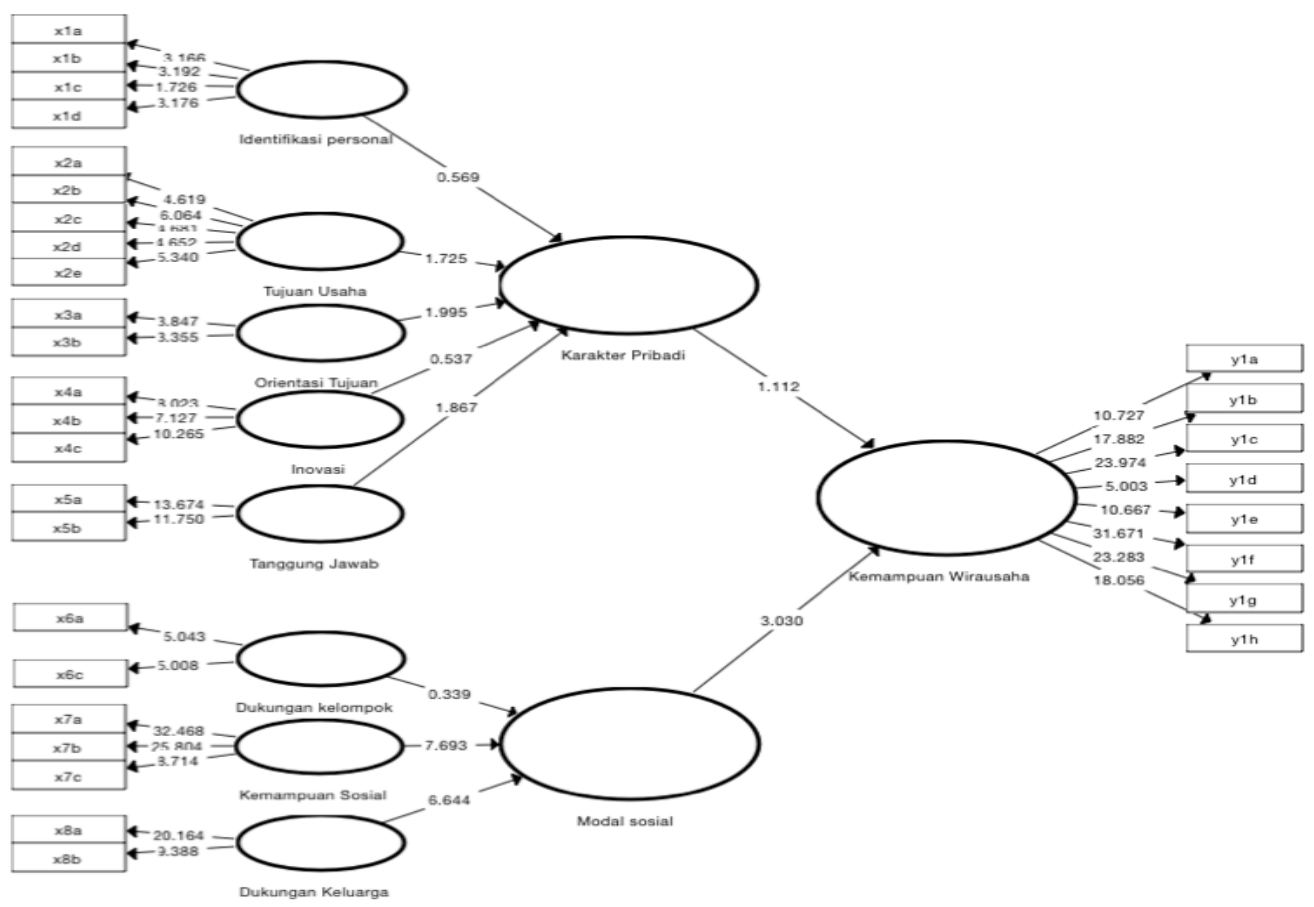

\section{Gambar 3. Nilai T-Statistics pada Diagram Jalur Persamaan Struktural PLS}

bahwa tidak adanya pengaruh yang signifikan antara karakter pribadi terhadap kemampuan wirausaha pada taraf nyata 5 persen. Gambar 3 menampilkan nilai $t$ statistics pada diagram jalur persamaan structural PLS.

Variabel karakter pribadi yang terbukti valid dan reliable adalah orientasi tujuan yang memberikan pengaruh positif terhadap karakter pribadi, dengan nilai path coefficient sebesar 0,348. Hal ini sesuai dengan hasil penelitian dari Kor et al. (2007) dan Chaudhary et al. (2012), dimana orientasi tujuan memainkan peran penting dalam membentuk kemampuan wirausaha dan mendorong keberhasilan wirausaha.

Orientasi tujuan berperan sebagai faktor yang mendukung pengambilan keputusan kewirausahaan, seperti di- nyatakan oleh Rauch dan Frese (2000). Pengambilan keputusan kewirausahaan sangat penting, baik pada tahap individu memulai kegiatan usaha maupun pada tahap mendorong kemajuan usaha. Hal ini juga menunjukkan adanya keinginan dari wirausaha perempuan untuk mendorong kemajuan usaha.

Hubungan identifikasi personal dengan karakter pribadi adalah negatif karena path coefficients bernilai -0,086, hal ini berbeda dengan hasil penelitian Ekpe (2011). Hubungan tersebut tidak signifikan karena nilai t-statistics lebih kecil dari t-table. Kurangnya pendidikan, pelatihan, dan pengalaman usaha membuat karakter pribadi mereka tidak berkembang. Hubungan antara tanggung jawab, inovasi, dan motivasi usaha dengan karakter pribadi secara masing- 
masing tidak terbukti signifikan, nilai $t$ statistics masing-masing hubungan lebih kecil dari $t$-table. Temuan ini tidak sesuai dengan hasil penelitian dari Kor et al. (2007) dan Chaudhary et al. (2012).

Hubungan tanggung jawab dengan karakter pribadi tidak terbukti signifikan dengan nilai path coefficient sebesar 0,347. Hal ini dapat disebabkan oleh keterbatasan kemampuan wirausaha perempuan dalam menjaga kualitas produk, pembayaran kredit, dan kedisiplinan dalam pengelolaan keuangan usaha. Hubungan inovasi dengan karakter pribadi tidak terbukti signifikan dengan nilai path coefficients sebesar 0,108.

Hal ini dapat disebabkan pemahaman inovasi usaha wirausaha perempuan masih sangat terbatas. Mayoritas jenis usaha yang dijalani sama yaitu makanan olahan dan minuman, serta toko kelontong. Hubungan tujuan usaha dengan karakter pribadi tidak terbukti signifikan dengan nilai path coefficients sebesar 0,240. Hal ini dapat disebabkan oleh sebagian besar motivasi wirausaha perempuan menjalankan usaha diakibatkan dorongan kebutuhan ekonomi, terbatas untuk menambah penghasilan rumah tangga.

Baron dan Markman (2000) menyatakan modal sosial dapat memengaruhi kesuksesan finansial wirausaha. Modal sosial juga turut memengaruhi motivasi, dan kemampuan wirausaha perempuan dalam menghadapi tantangan usaha (Okafor dan Amalu, 2010; Noureen dan Arsyad, 2011).

Pada Tabel 8, nilai t-statistics yang diperoleh dari hubungan antara peubah modal sosial terhadap kemampuan wirausaha lebih dari 1,96. Hal ini menunjukkan bahwa terdapat pengaruh yang signifikan antara modal sosial terhadap kemampuan wirausaha pada taraf nyata 5 persen.

Variabel modal sosial yang terbukti valid dan reliable adalah dukungan keluarga dan kemampuan sosial yang memberikan pengaruh positif terhadap modal sosial, dengan nilai path coefficient masing-masing sebesar 0,568 dan 0,618. Hal ini sesuai dengan hasil Baron dan Markman (2003); Noureen dan Arsyad (2012) yang mengungkapkan bahwa modal sosial memainkan peran penting dalam membentuk kemampuan wirausaha serta mendorong keberhasilan dalam wirausaha. Baron dan Markman (2003) menyatakan selain faktor eksternal seperti kepercayaan dan ikatan sosial, faktor internal yang dimiliki oleh wirausaha perempuan seperti kemampuan sosial dan karakter pribadi berperan dalam mendorong kesuksesan usaha.

Hubungan dukungan keluarga terhadap modal sosial signifikan karena nilai t-statistics lebih besar dari t-table. Hal ini menunjukkan terdapat dukungan yang baik dari orang tua serta keluarga inti terhadap perempuan untuk menjalankan usaha. Hubungan kemampuan sosial terhadap modal sosial signifikan karena nilai $t$-statistics lebih besar dari t-table. Hal ini menunjukkan bahwa wirausaha perempuan memiliki kemampuan sosial yang baik, seperti sikap keterbukaan dan aktif dalam menjalin pertemanan. Hal ini juga sesuai dengan Renzulli et al. (2000), yang menyatakan wirausaha perempuan juga cenderung melibatkan kerabat dalam mendirikan dan menjalankan usaha. 
Hubungan dukungan kelompok terhadap modal adalah negatif karena path coefficients bernilai -0,005. Hubungan tersebut tidak signifikan karena nilai $t$ statistics lebih kecil dari t-table. Hal ini bermakna tinggi rendahnya modal sosial tidak dipengaruhi oleh dukungan kelompok. Hubungan negatif ini dapat disebabkan oleh ketiadaan kelompok sosial. Hal ini menandakan ketiadaan kelompok sebagai ikatan lemah dalam lingkungan sosial mengakibatkan wirausaha perempuan kesulitan dalam memperoleh informasi, promosi, dan media untuk pengembangan usaha. Keberadaan kelompok sosial penting dalam membentuk motivasi dan mendorong kemajuan usaha, karena dapat memengaruhi baik identifikasi personal maupun karakter wirausaha perempuan (Okafor dan Amalu, 2010; Noureen dan Arsyad 2011).

Berdasarkan hal di atas, dapat disimpulkan bahwa faktor yang paling berpengaruh terhadap kemampuan wirausaha adalah modal sosial. Nilai path coefficient kemampuan sosial terhadap modal sosial sebesar 0,618. Hal ini menunjukkan bahwa wirausaha perempuan memiliki kemampuan sosial yang baik. Kemampuan sosial ini memiliki peran paling besar untuk menggambarkan modal sosial yang membentuk kemampuan wirausaha.

Hasil ini juga sesuai dengan temuan Loice dan Razia (2013) dan Jalila et al (2014) yang menemukan bahwa dalam pemberian program kredit mikro kepada wirausaha perempuan, pengembangan modal sosial memiliki peran penting dalam meningkatkan kemampuan teknis perempuan dalam menjalankan usaha mereka. Pemberian pelatihan usaha akan efektif dalam mendukung pengembangan karakteristik pribadi dan modal sosial wirausaha perempuan. Pemberian pelatihan dapat mengatasi kendala sistematis dalam konteks norma-norma sosial budaya yang membatasi perempuan desa untuk dapat produktif dan berkembang.

\section{KESIMPULAN DAN SARAN \\ Kesimpulan}

Karakter pribadi dan modal sosial berpengaruh positif terhadap kemampuan wirausaha perempuan. Modal sosial lebih berpengaruh terhadap kemampuan wirausaha dibandingkan dengan karakter pribadi. Adapun indikator-indikator yang memiliki kontribusi terbesar dalam menjelaskan variabel laten modal sosial adalah kemampuan sosial.

\section{Saran}

Dalam rangka peningkatan karakter pribadi dan modal sosial wirausaha perempuan, diperlukan program pemberdayaan, diantaranya dapat dilakukan dengan cara membentuk kelompok sosial dan pemberian program pelatihan serta pendampingan kepada wirausaha perempuan.

Program perlu perlu disesuaikan dengan kebutuhan perempuan desa, mengingat karakter pribadi, modal sosial dari perempuan desa sangat spesifik, disertai juga dengan karakteristik usaha mereka yang tergolong gurem. 


\section{DAFTAR PUSTAKA}

Adilah, N. 2014. Analisis Perilaku Wanita Wirausaha Terhadap Kredit (Studi Kasus Lingkar Kampus Institut Pertanian Bogor). [skripsi]. Bogor: Institut Pertanian Bogor.

Adler PS, Kwon SW. 2009. Prospects for a New Concept. The Academy of Management Review. 27(1):1740.

doi:10.5465/AMR.2002.5922314.

Afrin S, Islam N, Ahmed SU. 2008. A multivariate model of micro credit and rural women entrepreneurship development in Bangladesh. International Journal of Business and Management. 3(8), p169.

Baron RA, Markman, GD. 2003. Beyond social capital: The role of entrepreneurs' social competence in their financial success. Journal of Business Venturing, 18(1), 4160

Baum, J. R., \& Locke, E. A. 2004. The relationship of entrepreneurial traits, skill, and motivation to subsequent venture growth. Journal of applied psychology. 89(4), 587.

[Bird B. 1995. Toward a Theory of Entrepreneurial Competency. Advances Entrepreneurship: Firm Emergence and Growth. New York (US): JAI Press, 2, 51-72.

[BPS] Badan Pusat Statistik. 2014. Kabupaten Bogor dalam Angka. Bogor (ID) Badan Pusat Statistik.

Chaifetz, R. A. 2010. Two Must-Haves For Growth: Entrepreneurial Spirit and Focus On Core Competencies.
American Journal Of Business. 25(1), 5-7.

Chaudhary V, Rawat SS, \& Saxena P. 2012. Entrepreneurship and Challenges in Global Environment. VSRD-International Journal of Business and Management Research. 2 (5), 2012, 213-222.

Cheston S, Kuhn L. 2002. Empowering Women through Microfinance. New York (US): UNIFEM.

Das, M. 2000.Women Entrepreneurs from India: Problems, motivations and success factors. Journal of Small Business and Entrepreneurship. 15(4).

Develtere, P. \& Huybrechts, A. 2002. Evidence On The Social And Economic Impact of Grameen Bank And BRAC on the Poor in Bangladesh. Research Paper. Hoger Instituut Voor De Arbeid. Katholieke Universiteit Leuven.

Ekpe I, Norsiah BM, Razak RC. 2010. The Effect of Microfinance Factors on Women Entrepreneurs' Performance in Nigeria: A Conceptual Framework. International Journal of Business and Social Science. 1(2), 255-263.

Ekpe, I. (2011). Women entrepreneurs and economic development in Nigeria: Characteristics for success. International Journal of Business and Social Science. 2(1), 287-291.

Elizabeth R. 2008. Peran Ganda Wanita Tani dalam Mencapai Ketahanan Pangan Rumah Tangga di Pedesaan. Iptek Tanaman Pangan. 3(1). 
Ghozali I. 2008. Structural Equation Modelling Metode Alternatif dengan Partial Least Square. Edisi 2. Semarang (ID). Badan Penerbit Universitas Diponegoro.

Hakim L. 2011. Perkembangan Tenaga Kerja Wanita Di Sektor Informal: Hasil Analisa Dan Proxy Data Sensus Penduduk. Among Makarti, 4 (7), 20-32.

[ILO] International Labor Organization. 2013. Tren Ketenagakerjaan dan Sosial di Indonesia 2013: Memperkuat peran pekerjaan layak dalam kesetaraan pertumbuhan. Jakarta: International Labor Office.

Khanka, SS. 2002. Entrepreneurial Development. New Delhi: S. Chand and Company Ltd.

[KKUKM] Kementerian Koperasi dan Usaha Kecil Menengah. 2010. Perkembangan Data Usaha Mikro, Kecil, Menengah (UMKM) Dan Usaha Besar (UB).

[KPPA] Kementerian Pemberdayaan Perempuan dan Perlindungan Anak. 2012. Kebijakan dan Strategi Peningkatan Produktifitas Ekonomi Perempuan (PPEP). Jakarta: KPPA.

Kor YY, Mahoney JT, Michael SC. 2007. Resources, capabilities and entrepreneurial perceptions. Journal of Management Studies. 44(7), 1187-1212.

Karlan DS, Valdivia M. 2006. Teaching entrepreneurship: Impact of business training on microfinance clients and institutions. Center discussion paper. Economic Growth Center. 941.
Khanka, SS. 2002. Entrepreneurial Development. New Delhi: S. Chand and Company Ltd.

Lavoori, V., \& Paramanik, R. N. 2014. Microfinance impact on women's decision making: a case study of Andhra Pradesh. Journal of Global Entrepreneurship Research. 4(1), 1-13. doi:10.1186/s40497-0140011-6

Loice M, Razia C 2013. Microfinance Interventions and Empowerment of Women Entrepreneurs Rural Constituencies in Kenya. Research Journal of Finance and Accounting. 4(9). 85-95.

Mitchelmore S, Rowley J. 2010. Entrepreneurial competencies: a literature review and development agenda. International Journal of Entrepreneurial Behavior \& Research. 16(2), 92-111.

Muljaningsih S, Soemarmo, Hadiwidjojo D, Mustajab MM. 2012. Faktorfaktor yang Mempengaruhi Minat Wirausaha Pengolahan Pangan Organik pada Perempuan Tani di Desa Wonokerto, Bantur, Malang. Wacana. 15(2), 12-18.

Müller, C. 2006. Faktor-Faktor yang Mempengaruhi Perempuan Pengusaha dalam Mendirikan dan Mengembangkan Usahanya di Propinsi NAD. Jakarta: Kantor Perburuhan International.

Noureen G, Arshad M. 2011. Effects of Social Capital On Micro Female Entrepreneurship In Pakistan. Research Paper. Universität Klagenfurt.

Okafor C., Amalu R. 2010. Entrepreneurial Motivations as 
Determinants of Women Entrepreneurship Challenges. Economic Science Series. LXII(2): 67-77.

Rauch, A., \& Frese, M. (2000). Psychological approaches to entrepreneurial success. A general model and an overview of findings. International Review of Industrial and Organizational Psychology. 15, 101-142.

Ringle, C. M., Wende, S., and Becker, J.M. 2015. "SmartPLS 3." Boenningstedt: SmartPLS GmbH, http://www.smartpls.com.

Safitri, LS. 2014. Dampak Kredit "Mitra AGB” pada Perempuan Wirausaha "Gurem” di Desa Cihideung Ilir, Kecamatan Ciampea, Kabupaten Bogor. [tesis]. Bogor: Sekolah Pascasarjana, Institut Pertanian Bogor.

Sharma, A., Dua, S., \& Hatwal, V. 2012. Micro enterprise development and rural women entrepreneurship: way for economic empowerment. Artha Prabandh: A Journal of Economics and Management. 1(06).

Suharyanto, A. 2007. Dampak Keberadaan IPB Terhadap Ekonomi Masyarakat Sekitar Kampus Dan Kontribusinya Terhadap Perekonomian Kabupaten Bogor. [tesis]. Bogor: Sekolah Pascasarjana, Institut Pertanian Bogor.

Tambunan, T. 2009. Women Entrepreneurs in Indonesia: Their Main Constraints and Reasons. Journal of Asia Entrepreneurship and Sustainability. 5(3): 37-51.
. 2012. Wanita Pengusaha di

UMKM di Indonesia: dan Kendala. Policy Discussion Paper Series. 33/01/2012. Centre for Industry, SME \& Business Competition Studies Trisakti Universty.

Vadde, V., \& Ratnam, N. V. (2014). The Impact of Self-Help Groups on Women Entrepreneurship: A Study. IUP Journal of Entrepreneurship Development. 11(3). 
Iqbal Reza Fazlurrahman, Anna Fariyanti, dan Suharno 